\title{
$\beta$-Cyclodextrin Nanocomplexes with Biologically Active Peptides from Hydrolysed Bovine Whey and Colostrum
}

\author{
Tatsiana M. Halavach ${ }^{1, * \mathbb{D}}$, Vladimir P. Kurchenko ${ }^{1 \mathbb{D}}$, Vasili G. Tsygankow ${ }^{2 \mathbb{D}}$, Ala M. Bondaruk ${ }^{2 \mathbb{D}}$, \\ Ekaterina I. Tarun ${ }^{3}$ (D), Vladimir A. Asafov 4 (D) \\ 1 Belarusian State University, Nezavisimosti Av. 4, 220030 Minsk, Belarus; halavachtn@gmail.com (T.M.H.), \\ kurchenko@tut.by (V.P.K.); \\ 2 RUE «Scientific Practical Centre of Hygiene», Akademicheskaya Str. 8, 20012 Minsk, Belarus; vgz@tut.by (V.G.T.), \\ bam-1969@tut.by (A.M.B.); \\ 3 International Sakharov Environmental Institute of Belarusian State University, Dolgobrodskaya Str. 23/1, 220070 Minsk, \\ Belarus; ktarun@tut.by (E.I.T.); \\ 4 All-Russian Research Institute of Dairy Industry, Lusinovskaya Str. 35/7, 115093 Moscow, Russia; v_asafov@vnimi.org \\ (V.A.A.); \\ * Correspondence: halavachtn@gmail.com (T.M.H.);
}

Received: 27.10.2021; Revised: 29.11.2021; Accepted: 2.12.2021; Published: 12.10.2021

Abstract: $\beta$-Cyclodextrin nanocomplexes with extensive whey and colostrum hydrolysates possessing acceptable flavor properties serve as potential sources of bioactive peptides. In this study, comparative characterization of dairy protein hydrolysates and their complexes with $\beta$-cyclodextrin is presented. Antioxidant activity of studied samples was estimated by fluorometric method, the formation of clathrates with cyclic oligosaccharide was determined using thermogravimetric analysis. A significant decrease in bitterness of peptides included in cyclic oligosaccharides was established compared with samples of dairy hydrolysates. 2.1/1.3-fold increase in the antioxidant potential of $\beta$-cyclodextrin clathrates with whey/colostrum hydrolysates was recorded versus unbound peptide fractions. According to toxicological tests on Tetrahymena pyriformis, the samples of whey hydrolysate and the resulting nanocomplex were referred to as non-toxic and slightly hazardous compounds, respectively. The dynamics of body weight gain and the relative weight coefficient of internal organs revealed no differences compared to the control group of Rattus norvegicus. The data on differentiation of blood cells, their death, and cytogenetic disorders demonstrated that a sample of cyclic oligosaccharides with whey peptides is non-toxic at the maximum dosages allowable for administration. $\beta$-Cyclodextrin complexing with dairy peptides resulted in enhanced radical-reducing activity and improved flavor properties, making the clathrates promising and safe ingredients of special nutrition formulas.

Keywords: whey; colostrum; extensive dairy hydrolysates; $\beta$-cyclodextrin clathrates; bitterness; antioxidant activity; toxicological evaluation; cytogenetic effect.

(C) 2021 by the authors. This article is an open-access article distributed under the terms and conditions of the Creative Commons Attribution (CC BY) license (https://creativecommons.org/licenses/by/4.0/).

\section{Introduction}

Cyclodextrins (CDs), or cyclic oligosaccharides, are distinguished by a cone-shaped spatial structure with a hydrophobic niche, which accounts for the ability to harbor inclusion nanocomplexes with different compounds [1-3]. Increased solubility, resistance to physical and chemical factors, tolerance, and bioavailability were shown for clathrates in contrast to the separate biologically active substances [4,5]. CD complexing with peptides and amino acids is known to possess a pronounced bitter taste, leading to upgraded flavor [4,6-8]. Introduction of $\alpha-C D$ softened the bitterness of pure amino acid solutions (phenylalanine, tryptophan, proline, 
isoleucine, tyrosine, histidine) and soy peptides [7]. $5 \% \beta$-CD supply (as complexing agent) eliminated bitterness of $5 \%$ soybean hydrolysate solution by $90 \%$ [8]. Therefore, it appears natural that $\beta-\mathrm{CD}$ was recommended as a preferential component of functional nutrition. In another case, supramolecular complex (insulin/R8-carboxymethyl- $\beta-\mathrm{CD}$ ) tested on diabetic rat line showed a considerable rise in insulin permeability and excellent biological effect [9]. $\beta$-CD complex demonstrated increased resistance of antimicrobial peptides ABP-CM4 [10] and nisin [11] to proteolysis accompanied by stable biological activity.

Effective protection against oxidative stress is provided by various antioxidants that prevent and inhibit oxidative reactions [12,13]. According to the literature reports, the antioxidant activity (AOA) of natural compounds and their inclusion complexes with cyclodextrins was studied [14-20]. In the test system 2,2'-azino-bis(3-ethylbenzothiazoline-6-sulfonic acid (ABTS)-Trolox, increased AOA levels of rutin complexes with $\alpha-, \beta-\mathrm{CD}$, and its analogs resulted from enhanced stability of rutin [15]. In compliance with oxygen radical absorbance capacity (ORAC) and ABTS assays, the augmented antiradical properties of $\beta-C D$ and hydroxypropyl- $\beta-C D$ clathrates with resveratrol were accompanied by higher solubility of the test compound [16]. Nanostructures with CD were produced to raise the bioavailability of the highly active natural antioxidant curcumin, which was confirmed by 1,1-diphenyl-2-picrylhydrazyl (DPPH) radical scavenging assay [17]. In various test systems (ferric reducing antioxidant power, DPPH radical scavenging, and ABTS assays), AOA of $\beta$-CD clathrates with catechin tended to rise compared to the sole bioactive substance [18]. In the reaction with DPPH radical, higher AOA was found in a complex of caffeic acid with $\alpha$-CD rather than $\beta$-CD [19]. According to DPPH radical scavenging assay, hydroxypropyl- $\beta-C D$ and methyl- $\beta-C D$ nanostructures with rosmarinic acid possessed improved radical-reducing properties [20].

Antiradical properties of milk are mainly determined by the potential of protein fraction and, to a lesser extent, by minor components (vitamins and minerals) [21]. AOA of proteins and peptides is associated with reducing properties of amino acid residues of methionine, cysteine, tryptophan, and tyrosine. The elevated AOA of tyrosine and tryptophan is defined by the capacity of the phenolic and indolic groups, respectively, to serve as hydrogen donors. Cysteine transfers the sulfur hydrogen groups, whereas methionine is inclined to oxidation to methionine sulfoxide [22,23].

Enzymatic protein hydrolysates with an extensive degree of hydrolysis contain shortchain peptides and free amino acids showing hypoallergenic properties and specific bitter flavor [24-26]. This prevents the wide use of cleaved proteins in foodstuffs. The biologically active potential of milk protein hydrolysates is determined by the presence of specific peptides with antioxidant, antimicrobial, antimutagenic, immunomodulatory, and other activities [2729]. Concentrates of casein and whey fractions are used as substrates for manufacturing protein hydrolysates [30,31]. Colostrum (first milk), distinguished by high nutritional and functional value, is a promising feedstock for hydrolysate production [32-34].

The effect of enzymatic hydrolysis and fermentation on AOA of whey and colostrum protein components was evaluated [35]. The organoleptic properties and antioxidant potential of $\beta-\mathrm{CD}$ nanocomplexes with commercial hydrolysate of whey proteins [36] were characterized in the previous reports. Thus, ORAC assay of $\beta$-CD clathrates with whey hydrolysate demonstrated a considerable decline in bitterness and 1.6 times rise in antiradical properties compared with free peptides [36]. In addition, the impact of complexing on antibacterial capacity and antimutagenic potential of dairy hydrolysates was investigated [37]. 
Owing to the wide-spread application of clathrates in the food industry, it is vital to conduct a toxicological and hygienic evaluation of $\beta-C D$ nanocomplexes with dairy protein hydrolysates. Nowadays, ciliates Tetrahymena pyriformis (T. pyriformis) are successfully used to assess food and feed products' toxicity and biological value [38-40]. T. pyriformis culture was applied in our experiments to estimate the safety of resulting nanocomplexes. The cytotoxic and cytogenetic effects of the tested samples were analyzed following their enteral administration to random-bred white rats Rattus norvegicus ( $R$. norvegicus).

This research was aimed at producing $\beta$-cyclodextrin nanocomplexes with extensive colostrum and whey hydrolysates, evaluating their antioxidant potential, conducting toxicological tests, determining cytotoxic and cytogenetic effects.

\section{Materials and Methods}

\subsection{Production of $\beta$-cyclodextrin nanocomplexes with milk peptides.}

Extensive protein hydrolysates of whey and colostrum for clathrate complexing were produced at the Laboratory of Applied Biology (Faculty of Biology, BSU). Whey protein concentrate (specifications BY 100377914.550-2008), dry defatted colostrum (All-Russian Research Institute of Dairy Industry, Moscow, Russia), endopeptidase (Alcalase® 2.4L, EC 3.4.21.62, activity $2.64 \mathrm{U} / \mathrm{g}$, Sigma, USA) were applied in the hydrolysis process. The enzymatic reaction was carried out at enzyme/substrate ratio $5 \%$, temperature $50{ }^{\circ} \mathrm{C}$, and $\mathrm{pH}$ 7.4 during 2 and $3 \mathrm{~h}$ in an experiment with whey and colostrum, respectively. Subsequent fractionation of hydrolysates was performed using Filters Spin X-UF Concentrator 20 (separation capacity $5 \mathrm{kDa}$, Corning, UK). Solutions containing protein hydrolysates (peptide fraction with molecular mass $\leq 5 \mathrm{kDa}$ ) and $\beta$-CD (Roquette, France) were pooled in solids ratio 1:2. The resulting mixtures of peptides and cyclic oligosaccharides were shaken for $4 \mathrm{~h}$ at 50 ${ }^{\circ} \mathrm{C}$. The procedure of hydrolysates and nanocomplexes production was particularly described in the earlier study [37]. The bitterness level of tested samples was evaluated according to the procedure proposed by Linde et al. (2010) [8]. Whey and colostrum hydrolysates were used as bitterness controls. Total protein content in the samples was determined according to ISO 8968-1:2014 [41], solids ratio was defined in line with ISO 6731:2010 [42]. Clathrate and hydrolysate samples were freeze-dried under pressure 0.1 atm at temperature $-53{ }^{\circ} \mathrm{C}$ during 24-48 h for subsequent experiments.

\subsection{Thermogravimetric analysis of hydrolysates and clathrates.}

Thermal degradation parameters of hydrolysate and clathrate samples were established by differential scanning calorimetry (DSC) and thermogravimetric analysis (TGA) using TGA/DSC thermal analyzer (Mettler Toledo, Switzerland). The sample weight was $10 \mathrm{mg}$, resolution of the analysis equaled $1 \mu \mathrm{g}$. The process of thermal decomposition of samples under a gradual heating regime from $30{ }^{\circ} \mathrm{C}$ to $600{ }^{\circ} \mathrm{C}$ at the rate $5{ }^{\circ} \mathrm{C} / \mathrm{min}$ was monitored. TGA results were based on the data of differential thermogravimetry (DTG) and thermogravimetric (TG) analysis. Effective energy of activation $\left(\mathrm{E}_{\mathrm{a}}\right)$ was calculated according to Broido assay with TGA graphs. Pure substances ( $\beta-\mathrm{CD}$ and peptides) and mixtures thereof (solids ratio 2:1) were chosen as the control samples.

\subsection{Estimation of antioxidant activity.}


The antioxidant activity of experimental samples was evaluated by the fluorometric method (ORAC). It is based on the suppression of fluorescein (FL) fluorescence as a result of its oxidation by oxygen radicals and inhibition of this process by antioxidants. The technique presented in E.I. Tarun's (2014) paper [43] was applied in this research. The results of 3 independent experiments were expressed as the mean value \pm confidence interval, and $p$ values of less than 0.05 were considered statistically significant.

\subsection{Toxicological trials of experimental samples on ciliate T. pyriformis culture.}

$\beta$-CD provided by Roquette (France), whey protein hydrolysate and $\beta$-CD nanocomplex with whey peptides produced at Laboratory of Applied Biology (Faculty of Biology, BSU) served as objects of studies.

The toxicological expertise of the samples was carried out using T. pyriformis test culture at Laboratory of Systemic Problems of Food Hygiene, Scientific and Practical Centre of Hygiene (SPCH). The toxicity level was judged by the time sufficient to cause $50 \%$ mortality rate of $T$. pyriformis culture (was provided by SPCH collection) in the medium with a defined concentration of the toxicant (median lethal dose, $\mathrm{LD}_{50}$ ). The detailed methodology of the experiment was presented in the previous study [44].

Suspensions containing $25-250 \mathrm{mg} / \mathrm{ml}$ of $\beta-\mathrm{CD}$, whey protein hydrolysate, and clathrate were prepared. The inoculum of test culture from the stationary growth phase was added to each sample. The samples were incubated at $25{ }^{\circ} \mathrm{C}$ during $2-3 \mathrm{~h}$ and $24 \mathrm{~h}$ in case of an acute and subacute experiment, respectively. After incubation, parameters of intoxication were examined under the microscope.

Major toxicity parameters $\left(\mathrm{LD}_{50}\right)$ were grounded on the percentage of the mortality rate of test culture in the acute and subacute experiments. The cumulation coefficient in the acute experiment (K $\mathrm{K}_{\text {CuMacuta }}$ ) was calculated as the $\mathrm{LD}_{50}$ ratio of the subacute and acute experiment as described in the article by Halavach et al. (2015) [44].

2.5. Evaluation of cytotoxic and cytogenetic action of nanocomplexes on white rats Rattus norvegicus.

$\beta$-CD (Roquette, France) and $\beta$-CD nanocomplex with whey peptides (Laboratory of Applied Biology, Faculty of Biology, BSU) were used in the study.

The cytotoxic and cytogenetic effects of clathrate with whey hydrolysate after enteral administration to random-bred white rats $R$. norvegicus were investigated at the Laboratory of Industrial Toxicology (SPCH). Male Wistar rats weighing 180-200 g were engaged in the experiment. Test animals were kept under standard vivarium conditions and handled following the Principles of GLP [45].

Within the framework of the chronic experiment, the control and test groups of animals received either the solution of $\beta-\mathrm{CD}$ or its nanocomplex with whey peptides, respectively, at a concentration $75 \mathrm{mg} / \mathrm{ml}$. The maximum allowable dose of the solution $(5 \mathrm{ml})$ was enterally administered to each animal 5 times a week for 4 weeks to establish safety parameters and effects on the hematopoietic system. By 28 days of the experiment, relative mass coefficient was determined for the internal organs of test animals. Peripheral blood smears were prepared by the standard technique and stained with Giemsa dye. At least 500 leukocytes (neutrophils, eosinophils, monocytes, lymphocytes) were analyzed per animal. The number of cells with micronuclei was counted experimentally as described by Fenech et al. (2003) [46]. The 
frequency rate of leukocytes showing apparent signs of apoptosis and necrosis was calculated according to the method proposed by Nagami et al. (2002) [47].

Statistical data processing envisaged for each group computation of the mean value of the studied parameter and the standard deviation. Differences between groups were analyzed by the nonparametric method (Mann-Whitney test) and considered significant at $\mathrm{p}<0.05$.

\section{Results and Discussion}

\subsection{Comparative characterization of extensive dairy hydrolysates and their clathrates with} $\beta-C D$.

Experimental samples of $\beta$-CD nanocomplexes with colostrum and whey peptides were produced. Extensive dairy hydrolysates containing peptide fraction with molecular mass $\leq 5$ $\mathrm{kDa}$ and cyclodextrin clathrates with peptides were subjected to sensory evaluation. Comparative analysis of the samples' organoleptic properties and biological activities is presented in Table 1.

Table 1. Characterization of extensive dairy hydrolysates and corresponding nanocomplexes with $\beta$-CD.

\begin{tabular}{|c|c|c|c|}
\hline Sample name & $\begin{array}{c}\text { Bitterness } \\
\text { intensity points }\end{array}$ & $\begin{array}{c}\text { Antimutagenic activity*, } \\
\text { S. typhimurium TA } 98 \text { / } \\
\text { TA 100, \% }\end{array}$ & $\begin{array}{l}\text { Antibacterial action* against } \\
\text { S. aureus ATCC 6538 / } \\
\text { E. coli ATCC 8739, \% }\end{array}$ \\
\hline $\begin{array}{l}\text { Extensive whey hydrolysate } \\
\text { (EWH) }\end{array}$ & 8 & $\begin{array}{c}14.1-25.9 / \\
12.1-20.3 \\
\end{array}$ & $\begin{array}{c}7.2(\text { weak ABA }) / \\
16.4(\text { moderate ABA })\end{array}$ \\
\hline Complex $(\mathrm{EWH}-\beta-\mathrm{CD})$ & 5 & $\begin{array}{c}14.1-28.3 / \\
12.5-21.8\end{array}$ & $\begin{array}{c}8.6(\text { weak ABA) / } \\
22.7 \text { (moderate ABA) }\end{array}$ \\
\hline $\begin{array}{l}\text { Extensive colostrum } \\
\text { hydrolysate }(\mathrm{ECH})\end{array}$ & 10 & $\begin{array}{l}9.2-23.9 / \\
8.6-19.4\end{array}$ & $\begin{array}{c}13.5(\text { weak ABA) / } \\
41.4 \text { (moderate ABA) }\end{array}$ \\
\hline Complex $(\mathrm{ECH}-\beta-\mathrm{CD})$ & 5 & $\begin{array}{c}10.0-25.2 / \\
13.8-21.2\end{array}$ & $\begin{array}{c}17.9 \text { (moderate } \mathrm{ABA}) / \\
68.1 \text { (strong } \mathrm{ABA})\end{array}$ \\
\hline
\end{tabular}

* The data are presented in the article by Halavach et al. (2021) [37]. Antimutagenic/antibacterial activity was determined at (0.03-0.5)/1.0 mg of hydrolysate per plate/sapmle. ABA=antibacterial action.

Extensive hydrolysates displayed evident bitter taste (8-10 points on the decimal scale). The drastically mildened flavor of $\beta$-CD clathrates ( 5 points) was caused by entrapping amino acids with a specific taste in the cyclic oligosaccharide niche as described by Linde et al. (2010) [8]. Improving the organoleptic properties of nacocomplexes with whey and colostrum peptides was first mentioned in the article by Halavach et al. (2021) [37]. The highest bitterness of hydrolyzed colostrum may be explained by more extensive enzymatic cleavage of casein fraction from first milk versus whey proteins [35].

Our previous study also stated improvement in the organoleptic characteristics of $\beta-C D$ nanocomplexes with commercial hydrolysate of whey proteins [36]. According to literature data, $\alpha$ - and $\beta$-CD supply eliminated bitterness of free amino acids (phenylalanine, tryptophan, proline, isoleucine, tyrosine, histidine) and soybean protein hydrolysate $[7,8]$.

The antimutagenic and antibacterial capacity of hydrolysates and their clathrates was characterized earlier [37]. The Ames test revealed that the antimutagenic activity of nanocomplexes stayed on par with that of extensive dairy hydrolysates. The difference in induced mutation rate for tested samples was statistically insignificant. The data of the impedimetric method supported the assumption that $\beta-C D$ complexing stimulated the antibacterial effect of colostrum peptides. $\beta$-CD clathrates with antimicrobial peptides ABP-CM4 [10] and nisin [11] also possessed increased biological activity. 
Summing up, obtained $\beta$-CD nanocomplexes with colostrum and whey peptides are characterized by improved flavor properties and confirmed biologically active potential (antimutagenic and antibacterial action).

\subsection{Thermal degradation parameters of nanocomplexes and hydrolysates.}

Thermal decomposition dynamics of pure substances (hydrolysates of whey and colostrum, $\beta$-CD), mixtures thereof, and clathrates based on DTG/TG-profiles in the region of a dominant peak corresponding to $\beta$-CD thermal degradation are reflected in Table 2.

Table 2. Comparative characteristics of thermal destruction dynamics of control hydrolysate samples and the derived clathrates according to DTG/TG profiles (in the region of a dominant peak corresponding to thermal degradation of $\beta-C D)$.

\begin{tabular}{|c|c|c|c|c|}
\hline Sample name & $\begin{array}{c}\text { Temperature } \\
\text { procuring maximum } \\
\text { degradation rate } \\
\left(\mathbf{T}_{\text {Vmax }}\right),{ }^{\circ} \mathrm{C} \\
\end{array}$ & $\begin{array}{c}\text { Maximum } \\
\text { degradation } \\
\text { rate }\left(V_{\max }\right), \\
\mathbf{M g} /{ }^{\circ} \mathrm{C} \\
\end{array}$ & $\begin{array}{c}\text { Amount of sample } \\
\text { in the system at } \\
\mathbf{T}_{\text {Vmax }} \% \text { of initial } \\
\text { content } \\
\end{array}$ & $\begin{array}{c}\text { Energy of } \\
\text { activation } \\
\left(\mathbf{E}_{\mathbf{a}}\right)^{*} \\
\mathbf{k J} / \mathbf{m o l}\end{array}$ \\
\hline $\begin{array}{l}\text { Extensive whey hydrolysate } \\
\text { (EWH) }\end{array}$ & 268.3 & 0.029 & 80.9 & 76 \\
\hline Mixture (EWH: $\beta-C D=1: 2)$ & 297.5 & 0.290 & 68.8 & 118 \\
\hline Clathrate (EWH: $\beta-\mathrm{CD}=1: 2)$ & 305.1 & 0.150 & 55.6 & 105 \\
\hline $\begin{array}{l}\text { Extensive colostrum hydrolysate } \\
(\mathrm{ECH})\end{array}$ & 285.8 & 0.027 & 77.0 & 66 \\
\hline Mixture (ECH: $\beta-\mathrm{CD}=1: 2)$ & 289.7 & 0.300 & 72.4 & 125 \\
\hline Clathrate (ECH: $\beta-\mathrm{CD}=1: 2)$ & 289.7 & 0.140 & 64.3 & 107 \\
\hline$\beta$-cyclodextrin & 301.8 & 0.430 & 67.1 & 324 \\
\hline
\end{tabular}

* The data are partially presented in the article by Halavach et al. (2021) [37].

DTG profiles indicated the maximum weight loss of $\beta$-CD sample at $301.8^{\circ} \mathrm{C}$, with the highest thermal decomposition rate reaching $0.43 \mathrm{mg} /{ }^{\circ} \mathrm{C}$. In the case of whey protein, hydrolysate decomposition peaks with maximal values of mass decay were recorded at 159.6, $203.9,268.3$, and $541.3{ }^{\circ} \mathrm{C}\left(0.006,0.014,0.029\right.$, and $0.040 \mathrm{mg} /{ }^{\circ} \mathrm{C}$, respectively). Upon thermal break-down of a colostrum protein hydrolysate, the peaks of weight decline were detected at $158.8,285.8$, and $531.3{ }^{\circ} \mathrm{C}\left(0.016,0.027\right.$, and $0.055 \mathrm{mg} /{ }^{\circ} \mathrm{C}$, respectively).

It should be noted that DTG profiles of hydrolysate mixtures with $\beta$-CD represent an overlap of mass loss peaks of separate compounds (Figure 1). The shift of thermal degradation peak of cyclic oligosaccharides from 301.8 to $297.5 / 289.7^{\circ} \mathrm{C}$ was revealed during the analysis of mixtures containing whey/colostrum hydrolysates, respectively.

Clathrate samples retained the prevalent peak of $\beta$-CD thermal decomposition somewhat shifted in temperature and shape, whereas degradation peaks typical for peptide mixture were not observed, evidencing the generation of inclusion complexes. A shift of $\beta-C D$ thermal degradation peak from 297.5 to $305.1{ }^{\circ} \mathrm{C}$ and a decrease in the mass-loss rate of the sample from 0.29 to $0.15 \mathrm{mg} /{ }^{\circ} \mathrm{C}$ was shown for clathrate derived from cyclic oligosaccharide and whey hydrolysate as compared with peptide mixture (Figure 1a). This indicated an increased resistance of the clathrate sample to thermal degradation. A decrease in the rate of thermal degradation from 0.30 to $0.14 \mathrm{mg} /{ }^{\circ} \mathrm{C}$ was found for inclusion complex containing colostrum hydrolysate at the same melting temperature peak of $289.7^{\circ} \mathrm{C}$ (Figure 1b). In general, the enhanced thermal stability of peptides as components of clathrates with cyclic oligosaccharides was confirmed.

TG profiles demonstrated the larger weight loss of whey-based complex at the temperature of maximal $\beta$-CD degradation $(13.2 \%)$ than that of clathrate with colostrum 
hydrolysate $(8.1 \%)$ in comparison with peptide mixtures (Table 2 ). The data prove the superior thermal stability of colostrum-containing clathrate.

$\mathrm{E}_{\mathrm{a}}$ parameter of whey and colostrum hydrolysates as constituents of mixtures and clathrates was estimated to rise by 1.4-1.6 times and 1.6-1.9 times, respectively (Table 2). Thus, dairy peptides originating from colostrum and whey exhibit greater stability upon complexing and mixing with a cyclic oligosaccharide.

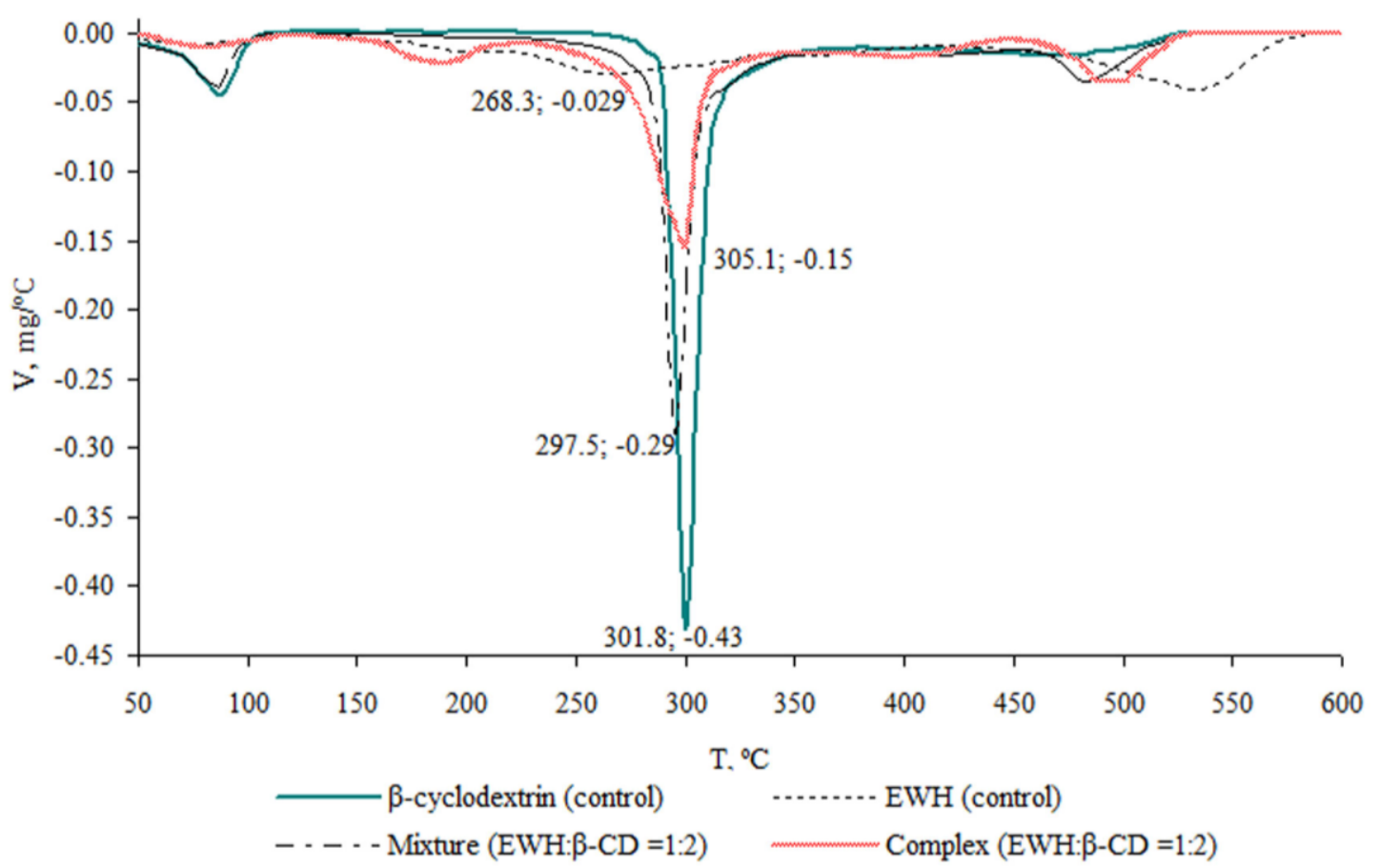

(a)

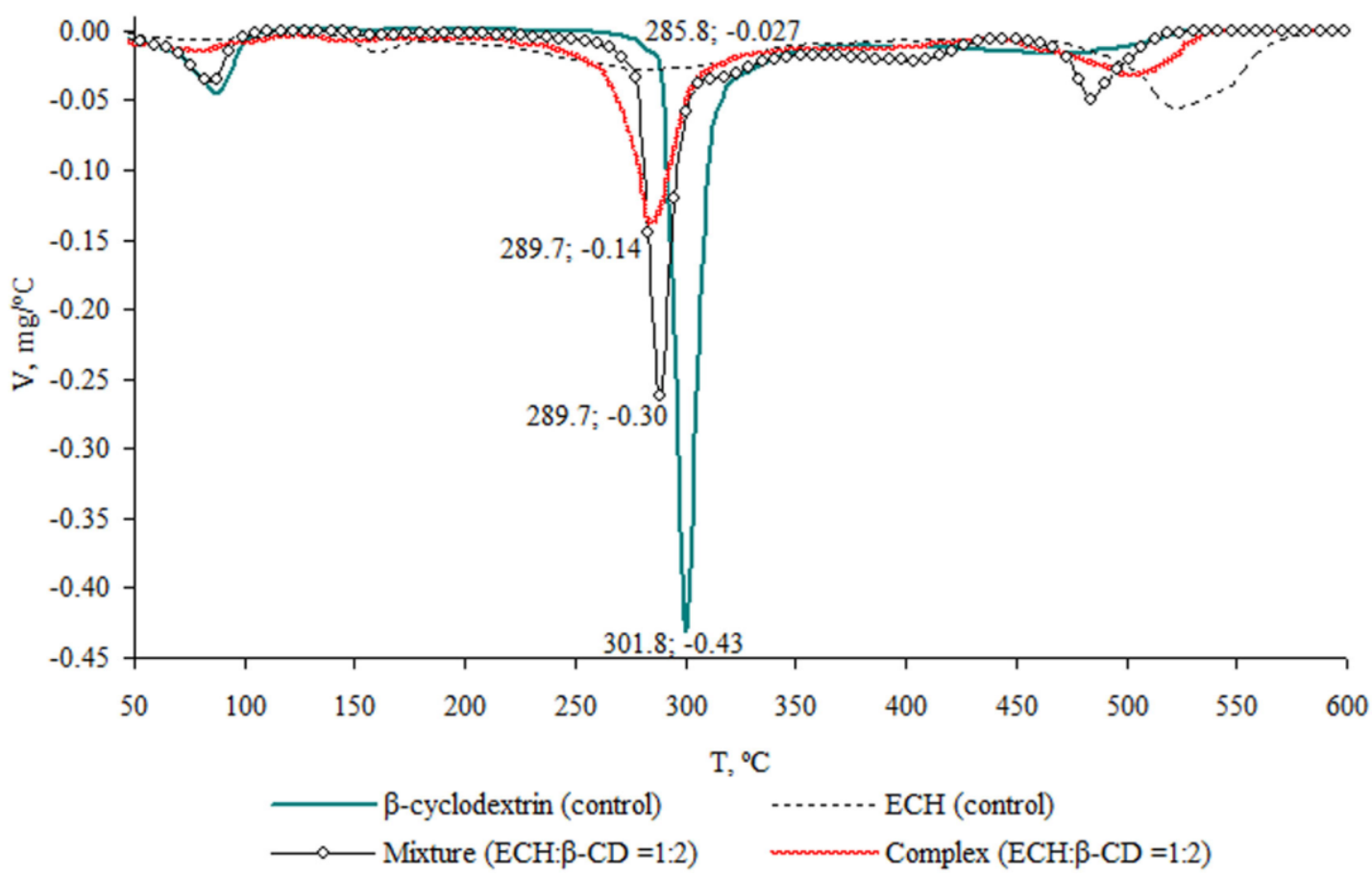

(b)

Figure 1. DTG-profiles of control and test samples of whey (a) and colostrum (b).

$\beta$-CD - $\beta$-cyclodextrin, EWH - extensive whey hydrolysate, ECH - extensive colostrum hydrolysate.

The earlier studies [36] also demonstrated the shaping of $\beta$-CD nanocomplexes with commercial hydrolysate of whey proteins and proved the remarkable thermal stability of peptide components of clathrates. 


\subsection{Antioxidant action of $\beta$-CD complexes with milk peptides.}

Antioxidant properties of clathrates with colostrum and whey peptides were determined. Correlations of FL fluorescence intensity with concentrations of dairy hydrolysates, cyclic oligosaccharides, and inclusion complexes were established. The experiments were conducted in a wide concentration range of studied compounds $(0.002-0.8$ $\mathrm{mg}$ solids $/ \mathrm{ml})$. The tested samples recovered FL fluorescence to 67-96\%. The sample concentrations corresponding to $50 \%$ inhibition of reactive oxygen species (the $\mathrm{IC}_{50}$ values) were graphically presented. The $\mathrm{IC}_{50}$ parameters were calculated relative to protein ratio and solids content in the composition of hydrolysates and clathrates, as reflected in Table 3.

Table 3. AOA parameters of extensive colostrum and whey hydrolysates and the respective clathrates.

\begin{tabular}{l|c|c}
\multicolumn{1}{c|}{ Sample name } & IC $_{\mathbf{5 0}}, \boldsymbol{\mu} \mathbf{g}$ solids/ml & IC $\mathbf{5 0}, \boldsymbol{\mu g} \mathbf{~ p r o t e i n} / \mathbf{m l}$ \\
\hline Whey $(\mathrm{W})$ & $117.6 \pm 10.6$ & $81.3 \pm 7.3$ \\
\hline Extensive whey hydrolysate $(\mathrm{EWH})$ & $24.8 \pm 0.6$ & $14.5 \pm 0.3$ \\
\hline Complex $(\mathrm{EWH}+\beta-\mathrm{CD})$ & $38.1 \pm 3.4$ & $6.9 \pm 0.6$ \\
\hline Colostrum $(\mathrm{C})$ & $104.7 \pm 4.7$ & $68.0 \pm 3.1$ \\
\hline Extensive colostrum hydrolysate $(\mathrm{ECH})$ & $20.4 \pm 1.8$ & $8.7 \pm 0.8$ \\
\hline Complex $(\mathrm{ECH}+\beta-\mathrm{CD})$ & $46.8 \pm 2.1$ & $6.7 \pm 0.3$ \\
\hline$\beta$-cyclodextrin & $114.9 \pm 0.3$ & -
\end{tabular}

$\mathrm{IC}_{50}$ values computed per solids concentration were comparable for intact dairy substrates (whey, colostrum) and $\beta$-CD. Enzymatic hydrolysis of whey/colostrum and further fractionation promoted AOA of peptide samples by 4.7/5.1 times (relative to solids content). Comparison of clathrates and hydrolysates pointed out the reduction of antioxidant activity with the shrinking of peptide fractions. Evaluation of $\mathrm{IC}_{50}$ parameters per content of protein component showed augmentation of radical-reducing action in cleaved and ultrafiltered whey/colostrum by 5.6/7.8 times. It was found that AOA of whey hydrolysate was 1.7 times higher than that of colostrum peptides. Complexing with $\beta-C D$ caused an increase in antiradical properties of whey/colostrum hydrolysates by 2.1/1.3 times compared with the respective peptide fractions. However, no significant distinctions were stated for both clathrate samples in the recovery of fluorescence levels.

In the different test systems (ABTS, ORAC, and DPPH radical scavenging assay), increased AOA levels of $\alpha$ - and $\beta$-CD complexes resulted from enhanced stability of some natural antioxidants (rutin, resveratrol, curcumin, catechin, caffeic, and rosmarinic acid) [15$20]$. According to literature sources [4,6-8], the production of clathrates with $\beta$-CD improved organoleptic properties of pure amino acids and soy protein hydrolysate. The previous paper [36] was focused on the growing antioxidant ability of inclusion complexes exceeding 1.3-1.6 times AOA level of commercial whey hydrolysate.

The present study investigated the effect of the complexing process on flavor and antiradical activity of obtained whey and colostrum hydrolysates. $\beta$-CD clathrates exhibited increased antioxidant potential surpassing 1.3 and 2.1 times the similar values of unbound peptide fractions of first milk and whey, respectively. The difference in AOA levels of native substrates (whey and colostrum) and their hydrolysates may be interpreted by peculiarities of protein-peptide composition (the ratio of casein to whey proteins) and degree of proteolysis with alcalase, and also the content of non-protein antioxidant constituent [35]. An increase in the antioxidant action of nanocomplexes may be associated with the rise in the solubility of the peptide fraction included in the clathrate structure. 
3.4. Toxicological evaluation of $\beta$-CD, extensive whey hydrolysate, and the derived clathrate.

Classification of the samples guided by the criteria of toxicity and safety was based on the results of evaluation tests on model organism $T$. pyriformis. The toxicity groups are summed up in Table 4.

Table 4. Toxicological classification of samples tested on $T$. pyriformis culture (as described in the previous study by Halavach et al. [44]).

\begin{tabular}{l|c|c|c|c|c}
\multirow{2}{*}{$\begin{array}{c}\text { Toxicity } \\
\text { index }\end{array}$} & \multicolumn{5}{|c}{ Classes denoting descent of toxicity and hazard level } \\
\cline { 2 - 6 } & $\begin{array}{c}\mathbf{1} \text { (extremely } \\
\text { hazardous) }\end{array}$ & $\begin{array}{c}\mathbf{2} \text { (highly } \\
\text { hazardous) }\end{array}$ & $\begin{array}{c}\mathbf{3} \text { (moderately } \\
\text { hazardous) }\end{array}$ & $\begin{array}{c}\mathbf{4} \text { (slightly } \\
\text { hazardous) }\end{array}$ & 5 (non-toxic) \\
\hline $\mathrm{LD}_{50}, \mathrm{mg} / \mathrm{ml}$ & $<0.1$ & $0.1-1.0$ & $1.1-20$ & $21-50$ & $>50$ \\
\hline $\mathrm{K}_{\mathrm{CUMacuta}}$ & $<0.1$ & $0.10-0.30$ & $0.31-0.49$ & $0.50-1.0$ & $>1.0$
\end{tabular}

A comparative examination of the toxicity parameters of $\beta-C D$, obtained extensive whey hydrolysate and $\beta$-CD complex with peptides regarding $T$. pyriformis culture is presented in Table 5. In line with the measured median lethal dose ( $\left.\mathrm{LD}_{50}\right)$, all tested samples may be referred to hazard class 5 (non-toxic compounds). Along with this, whey protein hydrolysate with an average degree of hydrolysis produced in the study by Halavach et al. [44] was also classified into the non-toxic group. According to the cumulation coefficient, the experimental nanocomplex of cyclic oligosaccharides with whey peptides belongs to hazard class 4 (slightly hazardous substance).

Table 5. Toxicity parameters of $\beta-C D$, whey hydrolysate, and the derived complex with $\beta-C D$.

\begin{tabular}{|c|c|c|c|}
\hline \multirow{2}{*}{ Toxicity parameter } & \multicolumn{3}{|c|}{ Sample name } \\
\hline & $\beta-C D$ & Whey protein hydrolysate (WH) & Complex $(\mathrm{WH}+\beta-\mathrm{CD})$ \\
\hline $\mathrm{LD}_{50}, \mathrm{mg} / \mathrm{ml}$ & $144.4 \pm 14.0$ & $296.4 \pm 2.1$ & $277 . \pm 1.3$ \\
\hline Hazard class $\left(\mathrm{LD}_{50}\right)$ & 5 & 5 & 5 \\
\hline $\mathrm{K}_{\text {CUMacuta }}$ & 1.23 & 1.03 & 0.62 \\
\hline Hazard class ( $\left.\mathrm{K}_{\text {CUMacuta }}\right)$ & 5 & 5 & 4 \\
\hline
\end{tabular}

3.5. Cytotoxic and cytogenetic effects of $\beta$-cyclodextrin complex with whey peptides.

The cytotoxic and cytogenetic effects of $\beta-\mathrm{CD}$ and its clathrate with whey hydrolysate were established after enteral administration to random-bred white rats $R$. norvegicus. The maximum allowable dose (375 $\mathrm{mg}$ to each animal, or $1,875-2,083 \mathrm{mg} / \mathrm{kg}$ ) was enterally administered 5 times a week for 4 weeks. Analysis of the dynamics of body weight gain and the relative weight coefficient of animal organs revealed no significant differences with the control group. This provides preliminary evidence of the safety of developed $\beta-C D$ composition with whey peptides.

Parameters of peripheral blood cell differentiation are presented in Table 6, and their cytogenetic characteristics are reflected in Table 7. Based on the analysis of blood cell differentiation, mortality, and cytogenetic disorders, it was concluded that the studied samples ( $\beta$-CD and its nanocomplex with whey hydrolysate) were not toxic even at the maximum dosages allowable for administration.

It was found that clathrate is likely to exert a potential, stimulating effect on the leukocyte cell pool. This was expressed as activation of cell differentiation, e.g., multinucleated forms (Table 6), along with the decline of cell death in vitro (Table 7). Enhanced cytogenetic effects of $\beta$-CD clathrate are probably due to its promoting impact on the cell proliferation and genetic damage processes within the framework of normal body response, which is confirmed by increased cell mortality rate in control in vitro. 
Table 6. Differentiation parameters of peripheral blood cells.

\begin{tabular}{|c|c|c|c|c|c|c|}
\hline \multirow{3}{*}{$\begin{array}{l}\text { Sample } \\
\text { name }\end{array}$} & \multirow{3}{*}{$\begin{array}{c}\text { Stab cells } \\
\text { (non-segmented cells) } \\
\%\end{array}$} & \multirow{2}{*}{\multicolumn{4}{|c|}{ Cells with segmented nucleus }} & \multirow{3}{*}{$\begin{array}{l}\text { Eosinophils } \\
\text { (excluding nucleus } \\
\text { segmentation) }\end{array}$} \\
\hline & & & & & & \\
\hline & & $\begin{array}{c}2 \text { segments, } \\
\%\end{array}$ & $\begin{array}{c}3 \text { segments, } \\
\%\end{array}$ & $\begin{array}{c}4 \text { segments, } \\
\%\end{array}$ & $\geq \underset{\%}{\geq 5 \text { segments, }}$ & \\
\hline$\beta-C D$ & $0.17 *$ & $0.17 *$ & $4.17 \pm 0.25$ & $2.0 \pm 0.57$ & $0.17 *$ & $0.17 *$ \\
\hline Complex & $2.0 \pm 0.57$ & $1.0 \pm 0.41$ & $0.17 *$ & $3.0 \pm 0.70$ & $1.50 \pm 0.50$ & $0.50 \pm 0.29$ \\
\hline \multicolumn{7}{|c|}{ Differentiation parameters after incubation during $24 \mathrm{~h}$ in vitro } \\
\hline$\beta-C D$ & $0.17 *$ & $0.17 *$ & $0.17 *$ & $0.17 *$ & $0.17 *$ & $0.17 *$ \\
\hline Complex & $2.0 \pm 0.57$ & $0.80 \pm 0.40$ & $0.17 *$ & $0.17 *$ & $0.17 *$ & $0.17^{*}$ \\
\hline
\end{tabular}

Table 7. Cytogenetic characteristics of peripheral blood cells.

\begin{tabular}{l|c|c|c|c} 
Sample name & Apoptosis, \% & $\begin{array}{c}\text { Cells with } \\
\text { micronuclei, \% }\end{array}$ & $\begin{array}{c}\text { Multiple mitoses, } \\
\text { \% }\end{array}$ & $\begin{array}{c}\text { Cytogenetic disorders (cells with } \\
\text { micronuclei, multiple mitoses, etc.), } \\
\text { \% }\end{array}$ \\
\hline$\beta$-CD & $2.0 \pm 0.57$ & $0.17^{*}$ & $0.17^{*}$ & $0.33 \pm 0.023$ \\
\hline Complex & $1.67 \pm 0.52$ & $1.0 \pm 0.41$ & $1.0 \pm 0.41$ & $2.0 \pm 0.57$ \\
\hline \multicolumn{4}{c}{ Cytogenetic characteristics after incubation during $\mathbf{2 4}$ h in vitro } \\
\hline$\beta$-CD & $6.0 \pm 0.97$ & $0.17^{*}$ & $0.17^{*}$ & $0.33 \pm 0.023$ \\
\hline Complex & $2.0 \pm 0.57$ & $0.17^{*}$ & $0.17^{*}$ & $0.33 \pm 0.023$ \\
$* 1$ cell was found in peripheral blood smear preparations
\end{tabular}

The EFSA Panel on Food Additives and Nutrient Sources added to Food (ANS) provides that $\beta$-CD has a low acute oral toxicity [48]. The main negative effect consisted in adaptive enlargement of the caecum caused consumption of low-digestible carbohydrates. According to 6-month study in rats, no observed adverse effect levels (NOAEL) of 600 $\mathrm{mg} / \mathrm{kg} /$ day were identified. In the case of rats' chronic $\beta$-CD toxicity studies, a NOAEL of 654 and $864 \mathrm{mg} / \mathrm{kg} /$ day in males and females, respectively, was revealed. Pursuant to carcinogenicity studies in mice and rats, no evidence of $\beta-C D$ negative action was established [48]. Along with the recommended levels of natural cyclodextrins for oral administration $[4,5,48]$, determining the safe amount of clathrates with cyclic oligosaccharides introduced into foodstuffs requires a separate study.

\section{Conclusions}

A comparative examination was carried out of $\beta-C D$ nanocomplexes with bovine whey and colostrum peptides. The taste of the obtained composite products was characterized by a considerable loss of bitterness compared to unbound extensive hydrolysates. The thermogravimetric study evidenced generation of clathrates with a cyclic oligosaccharide. Fluorometric investigations have shown that $\beta$-CD nanocomplex raised the antioxidant potential of peptide constituents derived from colostrum and whey hydrolysates by 1.3 and 2.1 times, respectively.

Preliminary toxicological trials of the studied compounds on test culture T. pyriformis allowed us to refer $\beta-\mathrm{CD}$ and whey protein hydrolysate at $\mathrm{LD}_{50}$ concentration to hazard class 5 (non-toxic substance). At the same time, $\beta$-CD complex with whey peptides corresponds to hazard class 4 (slightly hazardous compound). The cytotoxic and cytogenetic actions of the obtained nanocomplex with whey hydrolysate were evaluated following enteral administration to random-bred white rats $R$. norvegicus. It was found that the clathrate may induce a potential, stimulating effect on the leukocyte cell pool. Furthermore, cyclic oligosaccharide and its nanocomplex with whey peptides proved non-toxic at the maximum allowable dosages for administration.

Summing up, the application of $\beta$-CD nanocomplexes with extensive dairy hydrolysates possessing acceptable flavor parameters, confirmed antioxidant capacity, and 
safety as potential additives in specialized foodstuffs (for infant, sport, dietetic nutrition) appears an extremely attractive option.

\section{Funding}

This study, supported by the Ministry of Education of Belarus, was performed within the framework of the state research program "Biotechnology", subprogram "Molecular and Cellular Biotechnology" (grant No. 20190686).

\section{Acknowledgments}

This research has no acknowledgment.

\section{Conflicts of Interest}

The authors declare no conflict of interest.

\section{References}

1. Liu, J.; Ding, X.; Fu, Y.; Xiang, C.; Yuan, Y.; Zhang Y, Peng, Y. Cyclodextrins based delivery systems for macro biomolecules. Eur. J. Med. Chem. 2020, 212, https://doi.org/10.1016/j.ejmech.2020.113105.

2. Mohamadhoseini, M.; Mohamadnia, Z. Supramolecular self-healing materials via host-guest strategy between cyclodextrin and specific types of guest molecules. Coord. Chem. Rev. 2020, 432, https://doi.org/10.1016/j.ccr.2020.213711.

3. Gadade, D.D.; Pekamwar, S.S. Cyclodextrin based nanoparticles for drug delivery and theranostics. Adv. Pharm. Bull. 2020, 10, 166-183, https://doi.org/10.34172/apb.2020.022.

4. Astray, G.; Mejuto, J.C.; Simal-Gandara, J. Latest developments in the application of cyclodextrin host-guest complexes in beverage technology processes. Food Hydrocoll. 2020, 106, https://doi.org/10.1016/j.foodhyd.2020.105882.

5. Matencio, A.; Navarro-Orcajada, S.; García-Carmona, F.; López-Nicolás, J.M. Applications of cyclodextrins in food science. A review. Trends Food Sci. Tech. 2020, 104, 132-143, https://doi.org/10.1016/j.tifs.2020.08.009.

6. Tamura, M.; Mori, N.; Miyoshi, T.; Koyama, S.; Kohri, H.; Okai, H. Practical debittering using model peptides and related compounds. Agr. Biol. Chem. 1990, 54, 41-51, https://doi.org/10.1080/00021369.1990.10869906.

7. Linde, G.A.; Junior, A.L.; de Faria, E.V.; Colauto, N.B.; de Moraes, F.F.; Zanin, G.M. Taste modification of amino acids and protein hydrolysate by $\alpha$-cyclodextrin. Food Res. Int. 2009, 42, 814-818, https://doi.org/10.1016/j.foodres.2009.03.016.

8. Linde, G.A.; Junior, A.L.; de Faria, E.V.; Colauto, N.B.; de Moraes, F.F.; Zanin, G.M. The use of 2D NMR to study $\beta$-cyclodextrin complexation and debittering of amino acids and peptides. Food Res. Int. 2010, 43, 187-192, https://doi.org/10.1016/j.foodres.2009.09.025.

9. Yang, L.; Li, M.; Sun, Y.; Zhang, L. A cell-penetrating peptide conjugated carboxymethyl- $\beta$-cyclodextrin to improve intestinal absorption of insulin. Int. J. Biol. Macromol. 2018, 111, 685-895, https://doi.org/10.1016/j.ijbiomac.2018.01.077.

10. Li, J.-F.; Zhang, J.-X.; Wang, Z.-G.; Yao, Y.-J.; Han, X.; Zhao, Y.-L.; Liu, J.-P.; Zhang, S.-Q. Identification of $\alpha$-cyclodextrin inclusion complex of antimicrobial peptide CM4 and its antimicrobial activity. Food Chem. 2017, 221, 296-301, https://doi.org/10.1016/j.foodchem.2016.10.040.

11. Li, J.; Pan, D.; Yi, J.; Hao, L.; Kang, Q.; Liu, X.; Lu, L.; Lu, J. Protective effect of $\beta$-cyclodextrin on stability of nisin and corresponding interactions involved. Carbohydr. Polym. 2019, 223, https://doi.org/10.1016/j.carbpol.2019.115115.

12. Warraich, U.-A.; Hussain, F.; Kayani, H.U.R. Aging - Oxidative stress, antioxidants and computational modeling. Heliyon 2020, 6, https://doi.org/10.1016/j.heliyon.2020.e04107.

13. Hunyadi, A. The mechanism(s) of action of antioxidants: From scavenging reactive oxygen/nitrogen species to redox signaling and the generation of bioactive secondary metabolites. Med. Res. Rev. 2019, 39, 25052533, https://doi.org/10.1002/med.21592.

14. Chatzidaki, M.; Kostopoulou, I.; Kourtesi, C.; Pitterou, I.; Avramiotis, S.; Xenakis, A.; Detsi, A. $\beta$-Cyclodextrin as carrier of novel antioxidants: A structural and efficacy study. Colloid Surf. A-Physicochem. Eng. Asp. 2020, 603, https://doi.org/10.1016/j.colsurfa.2020.125262. 
15. Nguyen, T.A.; Liu, B.; Zhao, J.; Thomas, D.S.; Hook, J.M. An investigation into the supramolecular structure, solubility, stability and antioxidant activity of rutin/cyclodextrin inclusion complex. Food Chem. 2013, 136, 186-192, https://doi.org/10.1016/j.foodchem.2012.07.104.

16. Lucas-Abellán, C.; Mercader-Ros, M.T.; Zafrilla, M.P.; Gabaldón, J.A.; Núñez-Delicado, E. Comparative study of different methods to measure antioxidant activity of resveratrol in the presence of cyclodextrins. Food Chem. Toxicol. 2011, 49, 1255-1260, https://doi.org/10.1016/j.fct.2011.03.004.

17. Celebioglu, A.; Uyar, T. Fast-dissolving antioxidant curcumin/cyclodextrin inclusion complex electrospun nanofibrous webs. Food Chem. 2020, 317, https://doi.org/10.1016/j.foodchem.2020.126397.

18. Reddy, C.K.; Jung, E.S.; Son, S.Y.; Lee, C.H. Inclusion complexation of catechins-rich green tea extract by $\beta$-cyclodextrin: Preparation, physicochemical, thermal, and antioxidant properties. LWT 2020, 131, https://doi.org/10.1016/j.lwt.2020.109723.

19. Shiozawa, R.; Inoue, Y.; Murata, I.; Kanamoto, I. Effect of antioxidant activity of caffeic acid with cyclodextrins using ground mixture method. Asian J. Pharm. Sci. 2018, 13, 24-33, https://doi.org/10.1016/j.ajps.2017.08.006.

20. Veras, K.S.; Silveira, F.N.; Delagustin, M.G.; Teixeira, H.F.; Barcellos, T.; Henriques, A.T.; Bassani, V.L.; Koester, L.S. Complexation of rosmarinic acid with hydroxypropyl- $\beta$-cyclodextrin and methyl- $\beta$-cyclodextrin: Formation of 2:1 complexes with improved antioxidant activity. J. Mol. Struct. 2019, 1195, 582-590, https://doi.org/10.1016/j.molstruc.2019.06.026.

21. Zulueta, A.; Maurizi, A.; Frígola. A.; Esteve, M.J.; Coli, R.; Burini, G. Antioxidant capacity of cow milk, whey and deproteinized milk. Int. Dairy J. 2009, 19, 380-385, https://doi.org/10.1016/j.idairyj.2009.02.003.

22. Hernández-Ledesma, B.; Dávalos. A.; Bartolomé, B.; Amigo, L. Preparation of antioxidant enzymatic hydrolysates from $\alpha$-lactalbumin and $\beta$-lactoglobulin. Identification of active peptides by HPLC-MS/MS. J. Agric. Food Chem. 2005, 53, 588-593, https://doi.org/10.1021/jf048626m.

23. Corrochano, A.R.; Buckin, V.; Kelly, P.M.; Giblin, L. Invited review: Whey proteins as antioxidants and promoters of cellular antioxidant pathways. J. Dairy Sci. 2018, 101, 4747-4761, https://doi.org/10.3168/jds.2017-13618.

24. Dalabasmaz, S.; Dittrich, D.; Kellner, I.; Drewello, T.; Pischetsrieder, M. Identification of peptides reflecting the storage of UHT milk by MALDI-TOF-MS peptide profiling. J. Proteomics 2019, 207, https://doi.org/10.1016/j.jprot.2019.103444.

25. Alim, A.; Song, H.; Raza, A.; Hua, J. Identification of bitter constituents in milk-based infant formula with hydrolysed milk protein through a sensory-guided technique. Int. Dairy J. 2020, 110, https://doi.org/10.1016/j.idairyj.2020.104803.

26. Asafov, V.A.; Tankova, N.L.; Iskakova, E.L.; Golovach, T.N.; Kurchenko, V.P.; Nurmukhanbetova, D.E. Hydrolytic regulation of component properties. News Natl. Acad. Sci. Repub. Kaz. Ser. Geol. Tech. Sci. 2020, 6, 23-28, https://doi.org/10.32014/2020.2518-170X.126.

27. Tadesse, S.A.; Emire, S.A. Production and processing of antioxidant bioactive peptides: A driving force for the functional food market. Heliyon 2020, 6, https://doi.org/10.1016/j.heliyon.2020.e04765.

28. Zhao, C.; Ashaolu, T.J. Bioactivity and safety of whey peptides. LWT 2020, 134, https://doi.org/10.1016/j.lwt.2020.109935.

29. Shivanna, S.K.; Nataraj, B.H. Revisiting therapeutic and toxicological fingerprints of milk-derived bioactive peptides: An overview. Food Biosci. 2020, 38, https://doi.org/10.1016/j.fbio.2020.100771.

30. Dullius, A.; Goettert, M.I.; de Souza, C.F.V. Whey protein hydrolysates as a source of bioactive peptides for functional foods - Biotechnological facilitation of industrial scale-up. J. Funct. Foods. 2018, 42, 58-74, https://doi.org/10.1016/j.jff.2017.12.063.

31. Tacias-Pascacio, V.G.; Morellon-Sterling, R.; Siar, E.-H.; Tavano, O.; Berenguer-Murcia, Á.; Fernandez-Lafuente, R. Use of Alcalase in the production of bioactive peptides: A review. Int. J. Biol. Macromol. 2020, 165, 2143-2196, https://doi.org/10.1016/j.ijbiomac.2020.10.060.

32. Dzik, S.; Miciński, B.; Aitzhanova, I.; Miciński, J.; Pogorzelska, J.; Beisenov, A.; Kowalski, I.M. Properties of bovine colostrum and the possibilities of use. Polish Ann. Med. 2017, 24, 295-299, https://doi.org/10.1016/j.poamed.2017.03.004.

33. Eslamian, G.; Ardehali, S.H.; Baghestani, A.-R.; Shariatpanahi, Z.V. Effects of early enteral bovine colostrum supplementation on intestinal permeability in critically ill patients: a randomized, double-blind, placebo-controlled study. Nutrition 2018, 60, 106-111, https://doi.org/10.1016/j.nut.2018.10.013.

34. Lee, A.; Pontin, M.C.F.; Kosmerl, E.; Jimenez-Flores, R.; Moretti, D.B.; Ziouzenkova, O. Assessment of adipogenic, antioxidant, and anti-inflammatory properties of whole and whey bovine colostrum. J. Dairy Sci. 2019, 102, 8614-8621, https://doi.org/10.3168/jds.2019-16509.

35. Halavach, T.M.; Dudchik, N.V.; Tarun, E.I.; Zhygankov, V.G.; Kurchenko, V.P.; Romanovich, R.V.; Khartitonov, V.D.; Asafov, V.A. Biologically active properties of hydrolysed and fermented milk proteins. J. Microbiol. Biotechnol. Food Sci. 2020, 9, 714-720, https://doi.org/10.15414/jmbfs.2020.9.4.714-720.

36. Halavach, T.M.; Tarun, E.I.; Zhygankov, V.G.; Butina, A.D.; Kurchenko, V.P. Inclusion complexes of cyclodextrin with whey peptides: characteristic of antioxidant activity. Journal BSU (Biology) 2018, 3, 3-13, (in Russian). 
37. Halavach, T.M.; Savchuk, E.S.; Bobovich, A.S.; Dudchik, N.V.; Tsygankow, V.G.; Tarun, E.I.; Kharitonov, V.D.; Asafov V.A. Antimutagenic and antibacterial activity of $\beta$-cyclodextrin clathrates with extensive hydrolysates of colostrum and whey. Biointerface Res. Appl. Chem. 2021, 11, 8626-8638, https://doi.org/10.33263/BRIAC112.86268638.

38. Sinks, G.; Schultz, T. Correlation of Tetrahymena pyriformis and Pimephales toxicity: evaluation of 100 additional compounds. Environ. Toxicol. Chem. 2001, 20, 917-921, https://doi.org/10.1002/etc.5620200429.

39. Zhu, H.; Tropsha, A.; Fourches, D.; Varnek, A.; Papa, E.; Gramatica, P.; Oberg, T.; Dao, P.; Cherkasov, A.; Tetko, I.V. Combinatorial QSAR modeling of chemical toxicants tested against Tetrahymena Pyriformis. J. Chem. Inf. Model. 2008, 48, 766-784, http://doi.org/10.1021/ci700443v.

40. Gerhardt. A.; Ud-Daula, A.; Schramm, K.-W. Tetrahymena spp. (Protista, Ciliophora) as test species in rapid multilevel ecotoxicity tests. Acta Protozool. 2010, 49, 271-280.

41. ISO 8968-1:2014. Milk and milk products. Determination of nitrogen content. Part 1: Kjeldahl principle and crude protein calculation. Geneva, Switzerland: International Organization for Standardization (ISO); 2014.

42. ISO 6731:2010. Milk, cream and evaporated milk. Determination of total solids content (Reference method). Geneva, Switzerland: International Organization for Standardization (ISO); 2010.

43. Tarun, E.I. Comparison of antioxidant activities of gallic, coffee and chlorogenic acids. Proceedings of BSU 2014, 9, 186-191. (in Russian).

44. Halavach, T.N.; Kurchenko, V.P.; Zhygankov, V.G.; Evdokimov, I.A. Determination of physicochemical, immunochemical and antioxidant properties, toxicological and hygienic assessment of whey protein concentrate and its hydrolysate. Foods Raw Mater. 2015, 3, 105-114, http://doi.org/10.12737/13127.

45. OECD Series on Principles of Good Laboratory Practice and Compliance Monitoring. Number 1. OECD Principles of Good Laboratory Practice. Paris, France: Environment Directorate. Organisation for Economic Co-operation and Development (OECD); 1998.

46. Fenech, M.; Chang, W.; Kirsch-Volders, M.; Holland, N.; Bonassi, S.; Zeiger, E. HUMN project: detailed description of the scoring criteria for the cytokinesis-block micronucleus assay using isolated human lymphocyte cultures. Mutat. Res. Genet. Toxicol. Environ. Mutagen. 2003, 534, 65-75, https://doi.org/10.1016/S1383-5718(02)00249-8.

47. Nagami, K.; Kawashima, Y.; Kuno, H.; Kemi, M.; Matsumoto, H. In vitro cytotoxicity assay to screen compounds for apoptosis-inducing potential on lymphocytes and neutrophils. J. Toxicol. Sci. 2002, 27, 191203, https://doi.org/10.2131/jts.27.191.

48. Additives, E.Panel o.F.; Nutrient Sources added to, F.; Mortensen, A.; Aguilar, F.; Crebelli, R.; Di Domenico, A.; Dusemund, B.; Frutos, M.J.; Galtier, P.; Gott, D.; Gundert-Remy, U.; Leblanc, J.-C.; Lindtner, O.; Moldeus, P.; Mosesso, P.; Parent-Massin, D.; Oskarsson, A.; Stankovic, I.; Waalkens-Berendsen, I.; Woutersen, R.A.; Wright, M.; Younes, M.; Boon, P.; Chrysafidis, D.; Gürtler, R.; Tobback, P.; Arcella, D.; Rincon, A.M.; Lambré, C. Re-evaluation of $\beta$-cyclodextrin (E 459) as a food additive. EFSA Journal 2016, 14, https://doi.org/10.2903/j.efsa.2016.4628. 